\title{
Europe dilutes draft bioethics convention
}

Paris. The parliamentary assembly of the 32-member Council of Europe last week approved the draft European Convention on Bioethics. But the agreed text, which had been considerably watered down in comparison to an earlier version after opposition from Germany, faces a long haul before being approved by the Committee of Ministers and ratified by member states.

Indeed, the difficulty in approving the text - which is being billed as the first international treaty specifically to address the potential risks of progress in medicine and biology to the rights and freedoms of individuals - has highlighted the impossibility of achieving international consensus on bioethical issues.

Germany, for example, refused to withdraw its opposition to an article of the convention, which would have permitted research on 'non-viable' embryos that had not developed beyond 14 days. The new text leaves the question open by deleting any reference to embryo research, apart from banning embryo production for research purposes. "Germany didn't want to hear the term embryo research," say council officials.

Also at Germany's insistence, the new text would ban all genetic research on 'legally incapacitated persons', which would include both handicapped persons and children. But such research, which is essential to study many genetic diseases, is already permitted in countries such as France under strictly regulated conditions.

Changes to the initial draft of the convention were sufficient for it to obtain the approval of a majority of the council's parliamentary assembly meeting in Strasbourg last week. But as its provisions on legally incapacitated persons conflict with existing national legislation, these will have to be reworded before the convention is voted on by the Committee of Ministers. France, for example, could not legally adhere to the convention as it now stands.

Council officials say that the textual changes needed to resolve this dilemma will probably require the parliamentary assembly to vote on the convention again later this year. If so, the Committee of Ministers would not be able to vote on the text before around this time next year.

The outcome of such a vote is far from certain. Italy, for example, where the Roman Catholic Church has strong views on bioethics, last week voted against the whole text. Adoption of the convention by the ministers only requires a majority vote. But moves to open it for ratification by the member states can be vetoed by individual states.

Council officials claim that neither Germany nor Italy are likely to veto the convention. They argue that both countries will probably accept that any convention is better than nothing, and at worst opt out by refusing to ratify the text themselves. Formal adoption of the convention requires only that it be ratified by five member states, after which it becomes legally binding in all those states who ratify it. Declan Butler

\section{Germany eyes new ozone controls}

Munich. Germany's federal environment minister, Angela Merkel, has stepped up efforts to introduce nationwide laws to reduce environmental ozone concentrations by banning cars without catalytic converters on sunny summer days.

Her move follows the publication of Europe's first study of the effects of local traffic restrictions in a small geographical area, which indicated that ozone levels can be reduced only if controls are more widely applied.

The European Commission wants to go even further. It has proposed Europe-wide measures to be applied to both traffic and industrial emissions. A directive reducing ozone emissions from industrial and other sources was adopted by the European Union (EU) last December, and the commission is now working on further measures.

Ozone levels have been rising in all industrialized countries over the past

\section{MRC concordat 'under threat', say Lords}

London. Members of Britain's House of Lords voiced concern last week that future activities of the Medical Research Council (MRC) could come under threat if a 'concordat' between the MRC and the National Health Service (NHS) is substantially changed when it comes up for renewal later this year.

The agreement, signed in 1992, promises that health departments will cover the infrastructure and overhead costs of research projects supported by the MRC. But a task force set up by the Department of Health to look at support for research and development in the NHS said in its report last year that the agreement was "too open-ended" (see Nature 371, 275; 1994).

Giving evidence to a subcommittee of the Lords Select Committee on Science and Technology, Anthony Culyer, the chairman of the task force and professor of medical economics at the University of York, said the current arrangement amounted to a "blank cheque" for the MRC. "It didn't seem right to us that the written concordat says that the NHS would support whatever research the MRC chooses."

The task force did not recommend changes, but, according to Lord Perry of Walton, a member of the committee and a former member of the MRC, this is implied by the task force's conclusions.

But Lord Walton of Detchant, chairman of the subcommittee - and also a former member of the MRC - said it was "perfectly reasonable" for the MRC to determine research priorities. He added that there was a "sufficient mechanism" in place at present for the health department to make its wishes known to the MRC through representatives on the research council's committees. M. V. decade, and often exceed the warning levels contained in the EU directive of 360 micrograms per cubic averaged over one hour, in all of Germany's 16 Länder, one of the highest reported incidences of excessive ozone levels in Europe.

The recent test was carried out by the environment ministry in BadenWürttemberg. Cars without catalytic converters were kept off the roads in two neighbouring cities for four sunny days last summer. The tests showed that levels of NO fell by 30 per cent and volatile organic compounds (VOCs) by 15 per cent.

Both chemicals are involved in the formation of ozone, and catalytic converters reduce the release of $\mathrm{NO}$ and VOCs by 95 and 99 per cent respectively. But local ozone levels did not fall as neither chemicals were present at saturating concentrations.

Harald Schäfer, minister of the environment for Baden-Württemburg, argues that the results show that, to reduce ozone levels, traffic restrictions need to be implemented over a much larger area.

Merkel agrees, and wants to introduce federal laws giving individual Länder the freedom to restrict traffic when there is a risk of summer smog. Last November, Merkel and the regional ministers of the environment unanimously supported a proposal to change Germany's Air Quality Act to allow this.

If the proposal is accepted, cars without catalytic converters and diesel cars with high pollutant emission levels will be banned from travel on high-risk days. But it has not yet been decided if the same restriction will be imposed on lorries, or whether industrial emissions will also be subject to control.

But the federal ministry of the environment is not likely to demand that speed limits be imposed. There is no evidence that such measures significantly affect ozone levels, and the issue is politically sensitive, as speed limits would be hotly opposed by the transport ministry.

Toni Feder 